\title{
OKPROPERTI.COM BUSINESS STRATEGY FOR VILLA SALES IN BALI DURING THE COVID-19 PANDEMIC
}

\author{
IGPB. Sasrawan Mananda ${ }^{1}$, Ida Bagus Made Mahendra ${ }^{2}$, I Wayan Darsana ${ }^{3}$ \\ Email: gusmananda@unud.ac.id ${ }^{1}$,ibmahendra@unud.ac.id ${ }^{2}$, darsana_ipw@unud.ac.id ${ }^{3}$ \\ ${ }^{1,2,3}$ Program Studi Industri Perjalanan Wisata, Fakultas Pariwisata, Universitas Udayana
}

\begin{abstract}
Abstrak: Pandemi Covid-19 telah mengubah kebiasaan masyarakat dalam menjalankan aktivitasnya, termasuk dalam memenuhi kebutuhannya dari offline menjadi online, meski aktivitas ekonomi sempat menurun, namun peluang untuk memperoleh penghasilan tetap terbuka, termasuk jual beli properti vila di Bali. melalui platform online. Salah satu platform yang baru terbentuk salah satunya adalah okproperti.com. Selama masa pandemi sekitar 4 juta orang di Indonesia setiap bulan mencari properti di Bali dan dua dari tiga orang ingin membeli properti dalam satu tahun ke depan dan selama hampir dua kuartal berturut-turut tahun ini, kata indeks harga villa terus menurun. Permintaan listing properti terus cenderung meningkat, meski pada saat lockdown mengalami penurunan, namun pada Agustus 2020 terjadi peningkatan yang menandakan minat properti mulai meningkat. Peningkatan penjualan villa didorong oleh berbagai faktor, selain harga yang lebih rendah; pemerintah juga memberikan potongan $100 \%$ pajak pertambahan nilai yang ditanggung pemerintah untuk pembelian rumah. Selain itu, suku bunga kebijakan Bank Indonesia saat ini berada pada level 3,5\%. Okproperti.com sebagai platform penyedia informasi penjualan properti memiliki strategi yaitu terus menyelaraskan apa yang dibutuhkan konsumen. Berdasarkan tren pencarian di okproperti.com, villa yang paling banyak dicari adalah villa minimalis dengan harga di bawah 2 Milyar Rupiah dengan fasilitas lengkap. Okproperti.com sebagai perusahaan teknologi properti, menjawab kebutuhan konsumen yang mencari informasi secara online, tidak hanya menghadirkan listing villa tetapi juga one stop solution termasuk legalitas, KPR agar para pencari villa mendapatkan rumah idaman.
\end{abstract}

\begin{abstract}
The Covid-19 pandemic has changed people's habits in carrying out their activities, including in fulfilling their needs from offline to online, even though economic activity had decreased, but the opportunity to earn income is still open, including buying and selling property villas in Bali through an online platform. One of the platforms that are newly formed one is okproperti.com. During the pandemic period around 4 million people in Indonesia every month are looking for property in Bali and two out of three people want to buy property within the next year and for almost two consecutive quarters this year, said the villa price index continued to decline. The demand for property listings continues to tend to increase, even though at the time of the lockdown it was decreasing, but in August 2020 there was an increase, which was a sign that interest in property was starting to rise. The increase in villa sales was driven by various factors, apart from lower prices; the government also provided a $100 \%$ discount on value added tax borne by the government for home purchases. Apart from that, Indonesia Bank's policy interest rate is currently at the level of $3.5 \%$. Okproperti.com as a property sales information provider platform has a strategy that is to continue to align what consumers need. Based on search trends on okproperti.com, the most sought-after villas are homes priced below 2 billion Rupiah with complete facilities. Okproperti.com as a property technology company, answers the needs of consumers who are looking for information online, not only presenting villa listings but also a one stop solution including legality, mortgages so that villa seekers get their dream home.
\end{abstract}

Keywords: business strategies, platform online. 


\section{INTRODUCTION}

Real Estate Indonesia (REI) explained that the property industry was severely affected during the pandemic. A Change in consumer patterns who came to malls for certain purposes only decreased by up to $85 \%$ during the pandemic. Then for hotels, where the occupancy rate fell by $90 \%$, even in Bali it reached $100 \%$ because there was no occupancy. Likewise, commercial house sales fell by $50 \%$ to $80 \%$ and only subsidized houses still survive and are in demand by consumers, especially those located in Bali. The Covid-19 pandemic has changed consumer behaviour in buying houses and obtaining property information. This change in new habits encourages developers to compete to switch to digital channels to attract consumers. In the midst of this year's business sluggishness, the company has increased marketing activities through digital channels; one of the brand new online platforms is okproperti.com. Before the pandemic, $70 \%$ of okproperti.com marketing was offline or via marketing galleries, exhibitions, while 30\% were online. In the current situation when many people are at home, the marketing strategy was changed to $70 \%$ and $30 \%$ offline, through digital marketing, by holding virtual tours to using key opinion leaders (KOL) or influencers in order to communicate products to consumers. Meanwhile, in terms of products, the habit of consumers being more at home has also changed the prevalence of comfortable homes, in this case there is a need for luxury homes in the form of villas.

\section{METHOD}

The research that will be carried out is using a descriptive qualitative research design, which is a research method that utilizes qualitative data and is described descriptively. The research method is the literature study method or literature study, which is a comprehensive overview of research that has been done on a specific topic to show readers what is already known about the topic and what is not known, to seek rationale from research that has been done or to further research ideas (Denney \& Tewksbury, 2013). The technique used in data collection in this research is the collection of literary data, namely materials that are coherent with the objects of discussion in question. The data collection process was carried out by filtering based on criteria determined by the authors of each journal taken.

\section{RESULTS AND DISCUSSION}

The impact of the corona pandemic, sales volume and property demand have decreased because many people are experiencing economic shocks so they don't think about investing in property or buying property. Rambey (2020), The property industry in Bali is very sensitive to the macroeconomic cycle of Indonesia, a decrease in income from the community will affect the people's purchasing power for property. In a CNBN news article, Indonesia stated that demand for and purchase of property fell quite significantly, especially when the pandemic first took place, where many cities carried out the lockdown, which cause in reducing the demand.

In 2019 property in Indonesia from the Ciputra group achieved sales of Rp. 3.9 trillion, while in 2020 it only reached Rp. 2.9 trillion, down $24 \%$. This is because property is not the first choice at a time of crisis like this.

Based on the analysis above, an exit strategy needed to immediately think of a strategy after the implementation of the lockdown has ended so that it can avoid negative effects on financial conditions of okproperti.com that are greater than the impact of the virus itself. How many strategies do we recommend among others: Being clarity about the business that is allowed to operate. Certainty of what can and can't be done is the key to smoothing activities and avoiding business panic. To apply this point, we can imagine exceptions to the lockdown policy granted on the basis of a self-declaration (with certificate) for businesses that meet certain criteria, including contributions to the supply chain of essential goods.

The gradual adoption of the lockdown policy by following strict health protocol rules that requires a clear strategy to return the economy to normal in stages, but with greater speed and clarity. The ad hoc list of newly permitted businesses will not remove the veil of uncertainty that obscures the overall 
economic conditions creating a zoning system for production clusters or regions as the basis for gradually enabling employees to return to work and businesses to resume operations.

Previously, people in Indonesia preferred to visit marketing galleries or see directly examples of houses being sold, nowadays digital media is the main choice. As many as $51.5 \%$ of respondents admitted to look for property information through developers' websites, $45.6 \%$ property aggregator sites, and $41.2 \%$ using social media which is used to see how the interior and design of the property.

In regards with communicating and interacting with customer, $55.9 \%$ of respondents expect virtual consultation via video conference, $52.9 \%$ virtual tour to see interior and exterior, and $51.5 \%$ use augmented or virtual reality (AR/VR) technology. These three aspects can be a golden opportunity for property developers to innovate in creating new experiences for the community digitally.

Nice design that millennial is interested in with smaller land sizes close to open spaces, and convenience stores. Within a month, okproperti.com can get 800 lists or consumers who start asking for products to put their contact numbers. Digital campaigns that go viral can provide a multiplier effect, although at the beginning of the pandemic the company's sales had decreased, but entering June 2020 sales began to increase by $15 \%$ and $13 \%$ above the target with the budget allocation for digital which is from $90 \%$ of the total advertising budget. Another strategy taken to attract prospective buyers is by offering subsidies for notary fees and taxes when buyers make down payments where okproperti.com staff improves services with speed of response by breaking the chain of complaints by solving problems that occur.

A result of research shows that searching for property information through digital platforms is increasingly in demand during the pandemic. The survey was conducted on 68 respondents throughout Indonesia with a profile of respondents dominated by Jakarta, Bogor, Depok, Tangerang and Bekasi (Jabotabek) people $54.4 \%$ with a profile of $25 \%$ not having a residence or would like to invest by buying villa property in Bali. With the stimulus interest difference subsidy and down payment subsidy that the government has disbursed, worth Rp. 1.5 trillion, which aims to save the property business in the midst of a pandemic.

From a tax perspective, it is hoped that the government will reduce the final rental income tax (PPh) and sale and purchase income tax to $5 \%$ and $1 \%$ respectively for a period of 12-18 months while also proposing that VAT be exempted, including for mediumsized villa, not only subsidized houses. In regards with the house the government regulates tax and time slack in payment times during the pandemic where the $17.5 \%$ tax paid to the state if the 10-year mortgage interest is calculated becomes $100 \%$.

This opens an opportunity for okproperti.com to provide a list of villas for sale. Research shows that villa market are currently dominated by the buyer age group of $22-29$ years $(36 \%)$ and 30-39 years $(29 \%)$. This is also seen as a new niche for providing affordable homes in the form of villas for millennial in the range of 600 million Rupiah to 1.3 billion Rupiah.

\section{CONCLUSION}

This COVID-19 outbreak has proven to have a very serious impact on every aspect of human life, including the economy that was shaken by it. For the property business economy, the impact is quite serious because this epidemic has an impact on every aspect of the property business, such as property demand, property prices, and mortgages.

In brief, okproperti.com's business strategy in marketing villa products is as follows: 1. Taking the millennial market share between 22-29 years old. 2. Prepare a house with a villa design ranging from 600 million 1.3 billion rupiah 3 . Conduct virtual consultations via video calls 4 . See villa products both interior and exterior in detail according to the current situation. 5. Provide fast service and solve problems quickly. 6 . Strengthening the network by collaborating with associations such as entrepreneur association and Junior Chamber International. 7. Providing subsidy or discount of villa purchase. 8. Good design with not a lot of land and strategic location. 


\section{Bibliography}

2019 Novel Coronavirus, Wuhan, China.World Health Organization (2020). Coronavirus. World Health Organization (2020). Novel Coronavirus (2019-nCoV).

Denney, A. S., \& Tewksbury, R. (2013). How to write a literature review. Journal of criminal justice education, 24(2), 218234.

Huang, et al. (2020). Clinical features of patients infected with 2019 novel coronavirus in Wuhan, China. The Lancet, 6736(20), pp. 1-10.

Keputusan Menteri Kesehatan Republik Indonesia Nomor HK.01.07/ Menkes/ m413/2020 Tentang Pedoman Pencegahan dan Pengendalian Coronavirus Disease 2019 (COVID19).

McKinsey (2020), Perspectives on Covid-19 and implications for consumer and retail companies by McKinsey \& Company in association with MMA, Jakarta, McKinsey \& Company.

OECD (2020), Evaluating the initial impact of COVID-19 containment measures on economic activity, Paris, Organisation for Economic Co-operation and Development.

Wang, et al. (2020). A Novel Coronavirus Outbreak of Global Health Concern. The Lancet, 6736(20), pp.1-4 Centers for Disease Control and Prevention (2020). 